\title{
Lactose Absorption in the Premature Infant*
}

\author{
EUGENE C. JARRETT and GERALD H. HOLMAN \\ From the Department of Pediatrics, Medical College of Georgia, Augusta, Georgia, U.S.A.
}

In 1921, while addressing the American Pediatric Society, John Howland described quite vividly the syndromes now recognized as congenital and acquired small intestinal disaccharidase deficiency. In his opening paragraph he stated that he hoped, 'to stimulate an interest to inquire more deeply into a subject on which our present knowledge is disappointingly scanty'. Yet it was not until 37 years later that attention was again brought to bear on this subject after Durand (1958) described a case of lactosuria and chronic diarrhoea, and Holzel, Schwarz, and Sutcliffe (1959) described two cases of suspected lactase deficiency. The only study to be found in this 37-year period is by Fox (1950) who reported sucrose absorption problems in sprue. Since 1959 however, several case reports and other studies related to the intestinal disaccharidases have been published (Weijers, van de Kamer, Dicke, and Ijsseling, 1961; Holzel, Mereu, and Thomson, 1962; Weijers, and van de Kamer, 1962; Auricchio, Dahlqvist, Mürset, and Prader, 1963; Anderson, Messer, Townley, and Freeman, 1963; Sunshine and Kretchmer, 1963; Cozzetto, 1963; Burgess, Levin, Mahalanabis, and Tonge, 1964; Sunshine and Kretchmer, 1964; Lifshitz and Holman, 1964; Davidson, Sobel, Kugler, and Prader, 1964; Auricchio, Rubino, Prader, Rey, Jos, Frézal, and Davidson, 1965b; Lifshitz, Klotz, and Holman, 1965; Burke, Kerry, and Anderson, 1965; Townley, Khaw, and Schwachman, 1965).

The purpose of this study was to determine if the premature infant, at 2 weeks of age, possessed normal intestinal disaccharidase activity as measured by oral tolerance tests. In addition, the question of whether or not there is substrate induction of disaccharidase activity in humans, as there appears to be in some animals (Fischer, 1957), was investigated.

\section{Material and Methods}

Twenty premature infants were divided at random into two groups at the time of their birth. One group was given a formula containing lactose as the only

Received February 4, 1966.

* Supported in Part by Grant HD-01483-02. disaccharide^. The other group was given a formula containing sucrose as the principal disaccharidet (Bernstein, 1965) until after the disaccharide tolerance tests were performed, and then this group was given the lactose-containing formula. Included in the study were two and a half sets of twins and one set of triplets. All infants were cared for in the premature intensive care unit, and any infant who had any significant difficulty, such as pneumonia or the respiratory distress syndrome, was excluded from the study.

Lactose, sucrose, and maltose tolerance tests were performed between 13 and 17 days of age on each infant by giving an oral load of $1.75 \mathrm{~g} . / \mathrm{kg}$. of the sugar in question after a 4-hour fast. True blood glucose was determined while fasting just before ingestion of the sugar and at 30,60, and 90 minutes after ingestion, using an ultramicro method (Keston and Teller, 1965) on heel prick blood.

\section{Results}

Twenty infants were studied, 10 in each group. There were 10 females and 10 males with both sexes equally divided between the two groups. In the lactose formula group, there were 7 Negro infants and 3 Caucasians, and this group had a birthweight range of 1250 to $1940 \mathrm{~g}$. with a mean birthweight of $1571 \cdot 3 \mathrm{~g}$. (SD 82.6). In the sucrose formula group, there were 9 Negro infants and one Caucasian, and this group had a birthweight range of 1170 to $2000 \mathrm{~g}$. with a mean birthweight of $1633.5 \mathrm{~g}$. (SD $85 \cdot 2$ ) . There is no significant difference between these two means.

The mean change in blood glucose with each tolerance test is illustrated in Fig. 1-3. As can be seen, there is very little difference between the groups during the maltose tolerance. Even though the group that was fed the lactose-free formula had a smaller mean blood glucose rise during the lactose and sucrose tolerance tests, the rise is significant and is within limits of normal using the criteria of Durand (1964). There is no statistically significant

\footnotetext{
* Lactose formula-SMA S26 (R) (Wyeth).

+ Sucrose formula-Nutramigen (R) (Mead Johnson).

$\ddagger$ Tabulated details of individual subjects are available on request to the authors.
} 


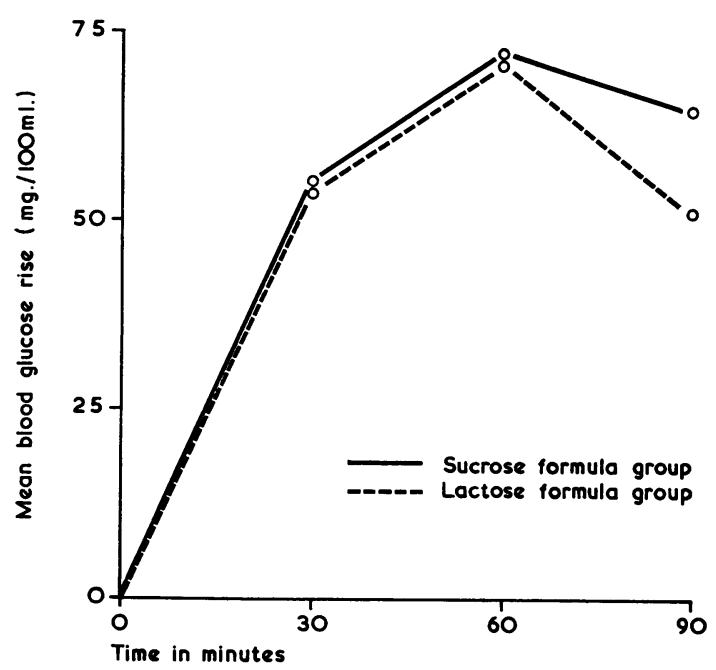

Fig. 1.-Lactose tolerance tests, showing mean true blood glucose rise for each group.

difference between the values obtained at comparative times between the two formula groups for any of the tolerance tests.

\section{Comment}

It has been shown quite clearly that the small intestinal disaccharidases are intracellular enzymes, and actually are located in the brush border portion of the small intestinal mucosal cells (Dahlqvist,

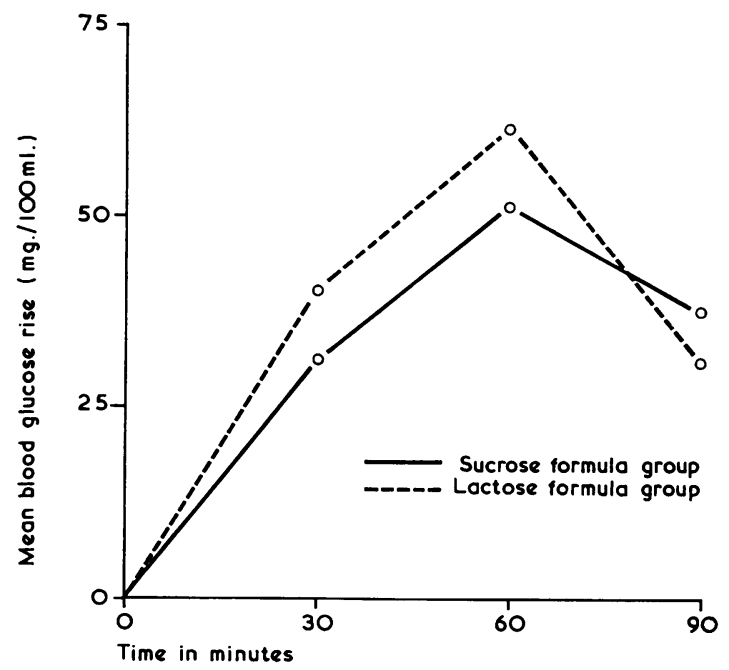

FIG. 3.-Sucrose tolerance tests, showing mean true blood glucose rise for each group.

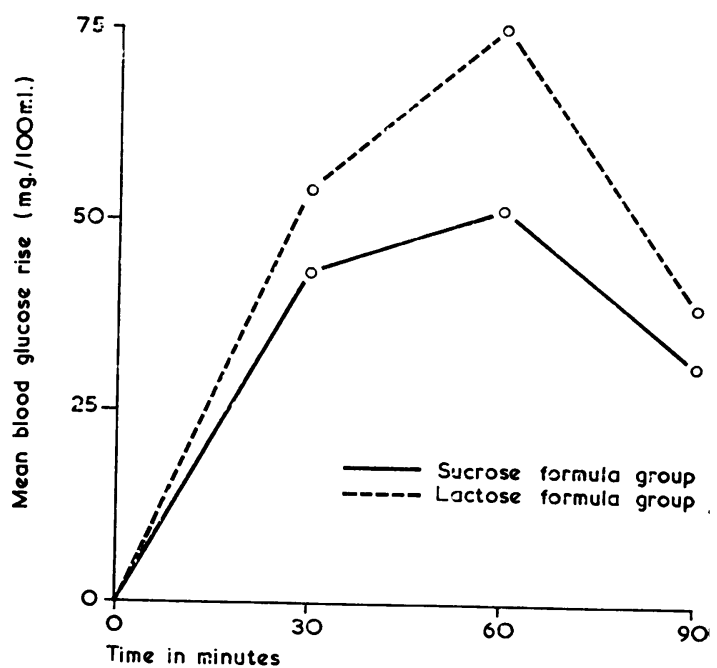

Fig. 2.-Maltose tolerance tests, showing mean true blood glucose rise for each group.

Auricchio, Semenza, and Prader, 1963; Doell and Kretchmer, 1962; Miller and Crane, 1961a, b). Auricchio, Rubino, and Mürset (1965a) have shown that the $\alpha$-glycosidases, maltase, sucrase, and others, can be found in human intestinal mucosal cells as early as the third foetal month, and that their activity increases thereafter until adult levels are reached between the sixth and eighth foetal months. The $\beta$-glycosidases, lactase and cellobiase, develop slightly later in intrauterine time and do not reach maximal activity until the end of normal gestation.

The rat, which has been used in much experimental work in this area, is born with a high level of lactase activity: however, this activity virtually disappears when the rat is weaned. Fischer (1957) has shown that if the rat is given a lactose load orally after the disappearance of his lactase activity, fermentative diarrhoea develops. If this lactose loading is continued, however, the rat will again develop sufficient lactase activity to hydrolyse the administered lactose. It was then postulated by some (Herzenberg and Herzenberg, 1959) that the intestinal lactase activity of the human infant might be substrate induced by the lactose present in the diet, or at least the presence of the lactose might increase the lactase activity.

The data presented in this paper illustrate that intestinal lactase, sucrase, and maltase activity is normal in the premature infant by 14 days of age, as measured by oral disaccharide tolerance tests. There is no indication of induction of lactase activity, since the infants who had had relatively 
lactose-free diets had blood glucose rises equivalent to those of the infants who had been fed lactose. The same findings were noted in regard to sucrose absorption in those infants with and without sucrose in the diet. These observations are supported by the findings of Barnett and Beard (1965), reported in a recent study on the ability of the newborn to utilize maltose. It may be possible that the small quantity of lactose in the low-lactose formula was sufficient to induce enzymatic activity, and further studies with formulas entirely free of lactose will be necessary to clarify this problem.

\section{Summary}

Oral lactose, sucrose, and maltose tolerance tests were performed on 20 premature infants at approximately 14 days of age. 10 infants had been on diets which contained lactose and 10 infants had been on relatively lactose-free diets containing sucrose as the principal disaccharide. The groups were the same regarding sex distribution, and there was no significant difference between the mean birth weights of the two groups.

Data are presented illustrating that lactase, sucrase, and maltase activities are normal in the premature infant at $\mathbf{1 4}$ days of age, as measured by oral disaccharide tolerance tests. It is also shown that the presence of the substrate sugar in the diet preceding the testing did not appear to induce or enhance the absorption activity of lactase or sucrase as measured by oral tolerance tests.

\section{REFERENCES}

Anderson, C. M., Messer, M., Townley, R. R. W., and Freeman, M. (1963). Intestinal sucrase and isomaltase deficiency in two siblings. Pediatrics, 31, 1003.

Auricchio, S., Dahlqvist, A., Mürset, G., and Prader, A. (1963), Isomaltose intolerance causing decreased ability to utilize dietary starch. F. Pediat., 62, 165.

—, Rubino, A., and Mürset, G. (1965a). Intestinal glycosidase activities in the human embryo, fetus, and newborn. Pediatrics, 35, 944.

- - Prader, A., Rey, J., Jos, J., Frézal, J., and Davidson, M (1965b). Intestinal glycosidase activities in congenital malabsorption of disaccharides. F. Pediat., 66, 555.

Barnett, T., and Beard, A. G. (1965). Utilization of maltose by the newborn infant (Abstract). Proc. Soc. Soc. pediat. Res., No. 49.

Bernstein, R. E. (1965). Studies on the metabolism and nutritional therapy of the galactosaemic infant and child. S. Afr. med. F., 39, 1170.

Burgess, E. A., Levin, B., Mahalanabis, D., and Tonge, R. E. (1964). Hereditary sucrose intolerance: levels of sucrase activity in jejunal mucosa. Arch. Dis. Childh., 39, 431.
Burke, V., Kerry, K. R., and Anderson, C. (1965). The relationship of dietary lactose to refractory diarrhea in infancy. Aust. pediat. $\mathcal{F}$., $1,147$.

Cozzetto, F. J. (1963). Intestinal lactase deficiency in a patient with cystic fibrosis. Pediatrics, 32, 228.

Dahlqvist, A., Auricchio, S., Semenza, G., and Prader, A. (1963). Human intestinal disaccharidases and hereditary disaccharidase intolerance. The hydrolysis of sucrose, isomaltose, palatinose (isomaltulose), and a 1 : $6 \alpha$-oligosaccharide (iso-maltooligosaccharide) preparation. f. clin. Invest., 42, 556.

Davidson, M., Sobel, E. H., Kugler, M. M., and Prader, A. (1964). Intestinal lactase deficiency of presumed congenital origin in two older children (Abstract). Gastroenterology, 46, 737.

Doell, R. G., and Kretchmer, N. (1962). Studies of small intestine during development. I. Distribution and activity of $\beta$ galactosidase. Biochim. biophys. Acta (Amst.), 62, 353.

Durand, P. (1958). Lattosuria idiopatica in una paziente con diarrea cronica ed acidosi. Minerva pediat., 10, 706.

(1964). Disorders Due to Intestinal Defective Carbohydrate Digestion and Absorption, p. 71. II Pensiero Scientifico, Rome.

Fischer, J. E. (1957). Effects of feeding a diet containing lactose upon $\beta$-D-galactosidase activity and organ development in the rat digestive tract. Amer. F. Physiol., 188, 49.

Fox, H. J. (1950). Sucrose absorption in sprue. F. Lab. clin. Med., $35,622$.

Herzenberg, L. A., and Herzenberg, L. A. (1959). Adaptation to lactose. Nutr. Rev., 17, 65.

Holzel, A., Mereu, T., and Thomson, M. L. (1962). Severe lactose intolerance in infancy. Lancet, 2, 1346.

-, Schwarz, V., and Sutcliffe, K. W. (1959). Defective lactose absorption causing malnutrition in infancy. ibid., 1, 1126.

Howland, J. (1921). Prolonged intolerance to carbohydrates. Trans. Amer. pediat. Soc., 33, 11.

Keston, A. S. and Teller, J. D. (1965). Instruction Manual Beckman/ Spinco Ultramicro Analytical System, Tech. Bull. Glucose Ultramicro Adaptation. No. 6073 C.

Lifshitz, F., and Holman, G. H. (1964). Disaccharidase deficiencies with steatorrhea. F. Pediat., 64, 34.

-, Klotz, A. P., and Holman, G. H. (1965). Intestinal disaccharidase deficiencies in gluten-sensitive enteropathy. Amer. $\mathcal{F}$. dig. Dis., 10, 47.

Miller, D., and Crane, R. K. (1961a). The digestive function of the epithelium of the small intestine. I. An intracellular locus of disaccharide and sugar phosphate ester hydrolysis. Biochim. biophys. Acta (Amst.), 52, 281.

- and - (1961b). The digestive function of the epithelium of the small intestine. II. Localization of the disaccharide hydrolysis in the isolated brush border portion of intestinal epithelial cells. ibid., 52, 293.

Sunshine, P., and Kretchmer, N. (1963). Diarrhea and deficiency of intestinal disaccharidases. (Abstract) f. Pediat., 63, 844.

$\longrightarrow$, and - (1964). Studies of small intestine during development. III. Infantile diarrhea associated with intolerance to disaccharides. Pediatrics, 34, 38 .

Townley, R. R. W., Khaw, K. T., and Schwachman, H. (1965). Quantitative assay of disaccharidase activities of small intestinal mucosal biopsy specimens in infancy and childhood. ibid., 36, 911.

Weijers, H. A., and van de Kamer, J. H. (1962). Diarrhea caused by deficiency of sugar-splitting enzymes. II. Acta paediat. (Uppsala), 51, 371.

$\longrightarrow$ - D Dicke, W. K., and Ijsseling, J. (1961). Diarrhea caused by deficiency of sugar splitting enzymes. I. ibid., 50 , 55. 